\title{
Tree Water Stress and Insect Geographic Origin Influence Patterns of Herbivory by Borers in Green (Fraxinus pennsylvanica) and Manchurian (F. mandshurica) Ash
}

\author{
Holly M. Martinson, Chris Sargent, and Michael J. Raupp
}

\begin{abstract}
Emerald ash borer (EAB), Agrilus planipennis (Coleoptera: Buprestidae), is a devastating buprestid beetle introduced to North America from Asia. Asian ash trees exhibit resistance to EAB, likely due to a shared co-evolutionary history. Resistance to one pest, however, does not necessarily confer resistance to others. Should Asian ash be highly susceptible to North American herbivores, the utility of such species for hybridization, breeding programs, and establishment in managed landscapes could be compromised. Common urban problems, such as drought stress, can increase borer attack and survival and may further complicate the search for resistant plant material. The objectives of this study were to examine the relative susceptibility of green (Fraxinus pennsylvanica) and Manchurian (F. mandshurica) ash to EAB and indigenous borers and whether that susceptibility changed with drought stress. In a common garden experiment, EAB occurred more frequently and reached higher abundances in green than Manchurian ash. The frequency and abundance of bark beetles (Curculionidae), North American native clearwing borers (Sesiidae), and longhorn beetles (Cerambycidae) were similar in the two ash species. Generation time of EAB was uniformly one year and did not depend on ash species or water stress. Although borers increased as expected in stressed trees, the relative susceptibility of green and Manchurian ash to borers did not change. The findings suggest Manchurian ash may be resistant to several classes of borers, regardless of insect geographic origin, although these conclusions should be viewed with some caution until the results can be verified in larger trees.

Key Words. Agrilus planipennis; Ash Trees; Defense Free Space; Emerald Ash Borer; Fraxinus; Green Ash; Invasive Species; Manchurian Ash; Voltinism; Water Stress.
\end{abstract}

A key component of integrated pest management programs for woody plants is the deployment of resistant plant material (Raupp et al. 1992; Herms 2002). Traditional plant breeding and genetic engineering can be effective at creating resistance, but many years may be required to develop resistant materials (Herms 2002). On the other hand, existing cultivars and species can be screened for resistance to key pests and deployed much more rapidly in the face of lethal pest outbreaks (Raupp et al. 1992; Herms 2002).

Emerald ash borer (EAB), Agrilus planipennis (Coleoptera: Buprestidae), is the most serious threat to North American ash (Fraxinus spp.) since its discovery in Michigan in 2002 (Cappaert et al. 2005; Haack 2006). To date, in North America, EAB has killed millions of trees and spread to twentyfour states plus the District of Columbia (United
States) and two provinces (Canada) (USDA Forest Service and Michigan State University 2014), and threatens approximately eight billion ash trees in continental U.S. forestlands (Nowak 2003). Ash is also a major component of urban forests (MacFarlane and Meyer 2005; Cumming et al. 2006; Raupp et al. 2006). Kovacs et al. (2010) estimated that 17 million ash trees on developed lands are at risk from EAB, with USD $\$ 10.7$ billion in projected management costs over a 10 -year horizon.

North American ash species are susceptible to EAB but Asian ash species appear to be resistant. In a common garden experiment, Rebek et al. (2008) found that EAB caused substantially higher mortality for the North American species, green ash (F. pennsylvanica) and white ash (F. americana), than for the Asian species, Manchurian ash (F. mandshurica). In 
its native range, $\mathrm{EAB}$ rarely damages its native hosts and is considered a secondary pest (Liu et al. 2007). In the introduced range, even healthy trees can be attacked and killed within a few years (Cappaert et al. 2005; Poland and McCullough 2006; Klooster et al. 2014). The putative mechanisms of resistance for F. mandshurica include a rapid rate of wound browning, constitutive and induced phenolic compounds, lignans and their derivatives, and a unique proteome signature (Eyles et al. 2007; Cipollini et al. 2011; Whitehill et al. 2011; Whitehill et al. 2012).

The resistance of Asian ash species to EAB likely results from their long, shared evolutionary history, which North American ash clearly lack (Whitehill et al. 2012; Herms and McCullough 2014). Manchurian ash is therefore being considered in traditional and hybrid breeding programs, as well as for genetic engineering (Whitehill et al. 2012; Herms and McCullough 2014). Although Asian ash species such as Manchurian ash have effective defenses against $\mathrm{EAB}$, resistance to one pest does not necessarily confer resistance to others (Herms 2002). North American ash are attacked by a suite of other borers, including the banded ash clearwing borer, Podosesia aureocincta, the ash/ lilac clearwing borer, $P$. syringae, the redheaded ash borer, Neoclytus acuminatus, and bark beetles (family Curculionidae) (Johnson and Lyon 1994; Solomon 1995; Herms 2007). Should Manchurian ash lack effective defenses against such indigenous North American insects, its utility as a source of resistant plant material may be compromised.

Common urban problems, such as tree water stress, can increase borer attack and survival and may further complicate the search for resistant plant material (Raupp et al. 2010). Typically, tree water stress increases borer oviposition, survival, and relative growth rates in part due to the disruption of defensive chemical transport (Koricheva et al. 1998; Hanks et al. 1999; Huberty and Denno 2004). EAB has been reported to attack Manchurian ash under stressful conditions, such as drought and fire damage (Baranchikov et al. 2008), and green ash are known to be more susceptible to clearwing borers under stressful conditions (Cregg and Dix 2001).

The objectives of this study were to examine the relative susceptibility of green and Manchurian ash to EAB and indigenous North American borers and to determine whether that susceptibility might change with experimentally imposed drought stress. Additionally, reports indicate that the generation time of $\mathrm{EAB}$ may depend on environmental conditions (Duan et al. 2010; Siegert et al. 2010; Tluczek et al. 2011). Therefore, a third goal of this study was to determine the generation time of $\mathrm{EAB}$ and whether it changes with tree stress. To achieve these goals, potted green and Manchurian ash were exposed to a heavy infestation of EAB and indigenous North American borers, and the development of EAB and abundance of all borers were assessed for two years as a function of tree drought stress.

\section{MATERIALS AND METHODS}

\section{Ash Tree Exposure to EAB and Indig- enous Borers}

Forty-eight individuals each of Manchurian ash ( $F$. mandshurica 'Mancana') and green ash (F. pennsylvanica 'Marshall's Seedless') were acquired as bare root stock from a nursery outside the known range of EAB (Bailey Nurseries, St. Paul, Minnesota, U.S.) on April 6, 2009. All trees had an initial DBH $\approx 5 \mathrm{~cm}$. Trees were planted in $56.8 \mathrm{~L}$ pots with bark-based soilless potting media (Sunshine PX3 Series, Sun Gro Horticulture, Agawam, Massachusetts, U.S.), fertilized (16-4-8 Vigoro Tree, Shrub, and Evergreen Food, Spectrum Brands, Inc., Middleton, Wisconsin, U.S.) in early spring and early autumn, and watered daily until well established. No chemical pesticides were applied at any time. Trees were maintained in a cold frame until May 13, 2009, and then moved to a forested site in Alexandria, Virginia, U.S. (N 38 $\left.44^{\prime} 38^{\prime \prime}, \mathrm{W} 77^{\circ} 10^{\prime} 12.2^{\prime \prime}\right)$ where high numbers of $\mathrm{EAB}$ were detected in early spring. Trees were exposed to natural colonization by EAB and indigenous North American borers from nearby $(<30 \mathrm{~m})$ ash trees heavily infested with EAB and other borers. Heavy EAB flight was confirmed through the use of an attractant-baited, three-sided purple prism trap. From May 13 through June 30, all trees were watered daily to allow for root establishment before beginning watering treatments in July.

Three watering treatments were established to create a gradient in drought stress. Sixteen trees of each ash species were assigned randomly to one of three watering treatments: full, half, and low water availability. Trees assigned to the full watering treatment received ambient rainfall plus hand 
watering five days per week. Trees assigned to the half watering treatment were hand watered three days per week and fitted with plastic rain excluders. Trees assigned to the low watering treatment were fitted with plastic rain excluders and watered only to maintain survival based on observations of tree condition (i.e., wilting, marginal browning, leaf discoloration, leaf drop). Rain excluders were made of $3.5 \mathrm{~mm}$ thick, clear polyethylene sheeting (Husky brand, Poly-America, Grand Prairie, Texas, U.S.), were fastened with duct tape to the bole of the tree just above the soil surface, and were draped over the sides of the pot (Figure 1). Trees were watered to the point of saturation, as evidenced by runoff from drainage holes, and then watered to runoff again.

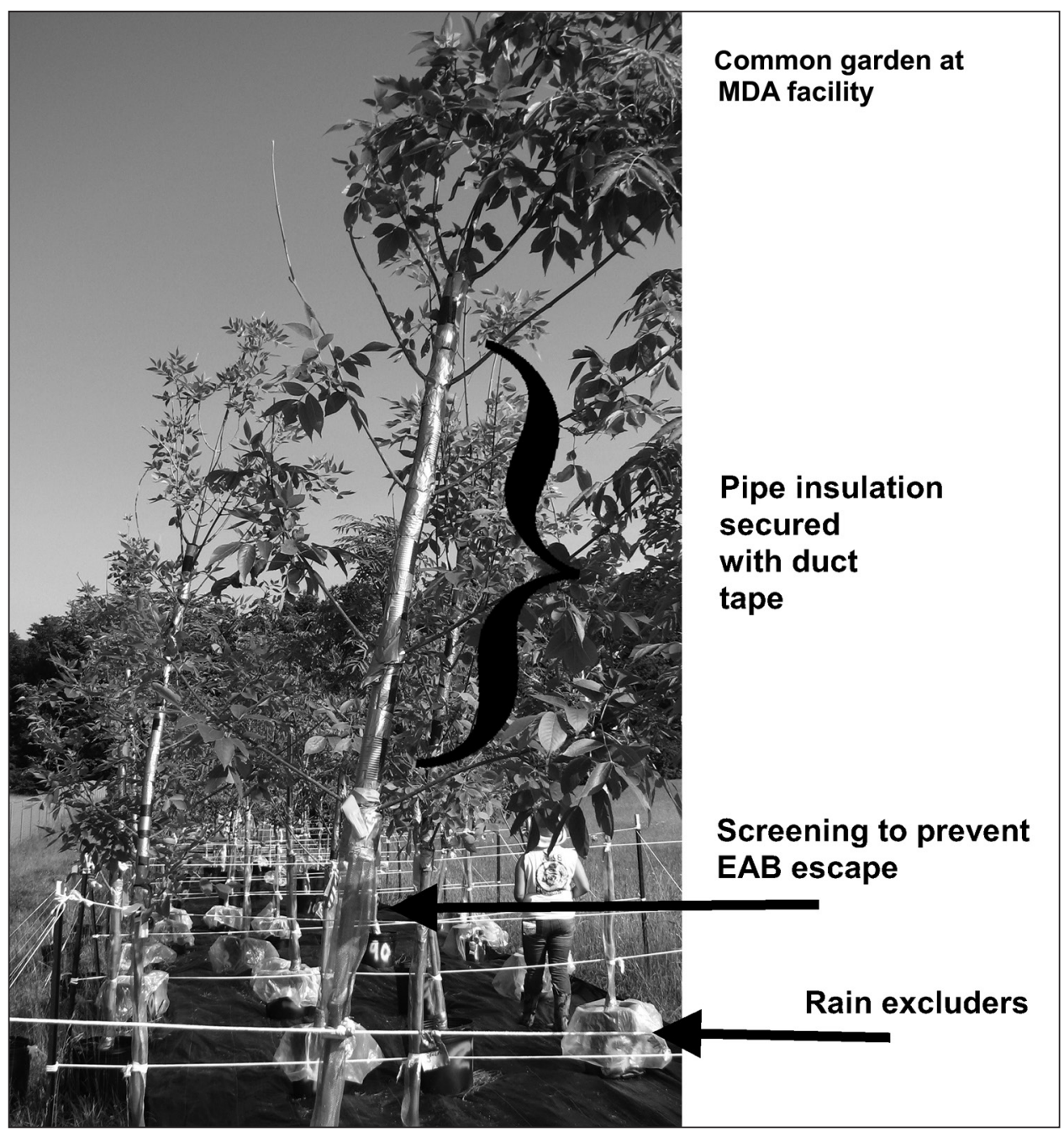

Figure 1. Experimental green and Manchurian ash trees at the Maryland Department of Agricultural (MDA) common garden site. To count borers, prevent their escape, and prevent colonization from additional borers during the second year of study, the boles, trunks, and major scaffold branches were enclosed in screening and pipe insulation. Drought stress treatments were imposed with plastic rain excluders.
Tree water stress was verified with a Handy PEA ${ }^{\oplus}$ chlorophyll fluorometer (Hansatech Instruments, Norfolk, UK). Chlorophyll fluorescence, measured in the field at regular intervals with a fluorometer, is an indicator of photoinhibition due to water stress (Maxwell and Johnson 2000). It is calculated as $\mathrm{F}_{\mathrm{v}} / \mathrm{F}_{\mathrm{m}}$. $\mathrm{F}_{\mathrm{v}}$ the variable fluorescence, is calculated as $\mathrm{F}_{\mathrm{m}}-\mathrm{F}_{\mathrm{o}}$, where $\mathrm{F}_{\mathrm{m}}$ is maximal fluorescence and $\mathrm{F}_{\mathrm{o}}$ is minimal fluorescence (Maxwell and Johnson 2000). This ratio of variable to maximal fluorescence indicates the maximal or potential photochemical efficiency of a plant and is a widely used indicator of plant health (Maxwell and Johnson 2000; Percival 2004; Percival et al. 2006). To examine drought tolerance in ash trees, Percival et al. (2006) determined that $\mathrm{F}_{\mathrm{v}} / \mathrm{F}_{\mathrm{m}}$ in healthy, nonstressed trees falls within the range of $0.76-0.85$, whereas $\mathrm{F}_{\mathrm{v}} / \mathrm{F}_{\mathrm{m}}$ in stressed ash trees was $<0.76$. These values were used to assess the extent of drought stress achieved in the experiment.

Chlorophyll fluorescence was measured at the beginning of the experiment prior to the imposition of water treatments and periodically throughout the experiment. Because of tree death (see Results), the number of times fluorescence was measured differed among trees. Chlorophyll fluorescence assessed early in the experiment (July 15, 2009August 26, 2009) corresponded with the flight period of EAB at this site. These fluorescence values were highly correlated with those taken through the whole first year (Pearson's correlation, $\mathrm{r}=0.99, \mathrm{t}_{93}=$ 74.8, $P<0.0001)$ as well as from the entire two-year experiment $\left(\mathrm{r}=0.99, \mathrm{t}_{93}\right.$ $=64.0, P<0.0001)$. Tree 
water stress was therefore evaluated as average chlorophyll fluorescence for the early part of the experiment during the time that $\mathrm{EAB}$ and other indigenous borers were active. Differences among watering regimes were evaluated with ANOVA followed by Tukey's post hoc multiple means comparisons, with a $95 \%$ family-wise confidence level.

At the end of the first summer, trees were prepared for overwintering in a cold frame and were watered during any week without precipitation that the temperature went above $12.8^{\circ} \mathrm{C}$. To determine the developmental stage of EAB and whether development depended on tree water stress, half of the trees were sacrificed and assessed in April 2010. This number included 21 trees that had died or were severely injured by treatments and exposure to borers during the first summer of the experiment, as evidenced by leaf loss, canopy thinning, and basal epicormic growth, plus 27 of the remaining 75 surviving trees. This group of 48 trees evaluated after the first year was comprised of 12 trees from the full, 12 from the half, and 24 from the low watering treatments.

The remaining 48 living trees were moved to a common garden at a Maryland Department of Agriculture (MDA) facility in Cheltenham, Maryland, U.S. (N 38 $43^{\prime} 52.7^{\prime \prime}, \mathrm{W} 76^{\circ} 50^{\prime} 3.1^{\prime \prime}$ ), which was near the center of the Maryland EAB Eradication Zone (Sargent et al. 2010). Trees were moved to this site to allow completion of borer development and evaluate EAB voltinism. To facilitate observation of emerging $\mathrm{EAB}$, prevent the escape of $\mathrm{EAB}$ into the eradication zone, and prevent additional borer attack, boles of trees were enclosed in fiberglass window screening (New York Wire, Grand Island, New York, U.S.) fastened to the tree with duct tape and $3.18 \mathrm{~cm}$ fiberglass pipe insulation (Frost King and Thermwell Products, Co., Inc., Mahwah, New Jersey, U.S.; Figure 1). The trunk above the first scaffold branch, and major scaffold branches (1-2 $\mathrm{cm}$ diameter) were enclosed in $1.91 \mathrm{~cm}$ polyethylene pipe insulation (Frost King and Thermwell Products, Co., Inc., Mahwah, New Jersey, U.S.; Figure 1). EAB purple prism traps hung within $50 \mathrm{~m}$ of the common garden and monitored weekly did not capture any EAB throughout the period of the study.

Watering treatments were reinitiated, and new plastic water excluders were placed as before on May 19, 2010. Using tree condition as a guide, water restrictions were suspended on trees in the half and low watering treatments periodically throughout the summer due to extreme heat. Once the EAB flight period ended, as indicated by trap data and observations made by MDA, screening and insulation were removed. Trees and insulation were examined for emerging borers. Watering treatments were maintained until October 4, 2010; trees were then overwintered following the same protocols as in 2009.

The ability of the screening and pipe insulation protocol to prevent borer colonization during the second summer was verified with cage control trees. Four potted green ash trees $(\mathrm{DBH} \approx 7.6 \mathrm{~cm})$ were obtained on May 13, 2010, from a nursery in Delaware, U.S., located outside the EAB quarantine zones. These trees were fitted with screening and pipe insulation and placed in a wooded site known to be heavily infested with EAB (Brandywine, Maryland, U.S., N 38 $42^{\prime} 17.6^{\prime \prime}$, W 76 53'57.5”). On July 21, 2010, after EAB flight ended, these control trees were transported back to the MDA facility and placed in the common garden with experimental trees for the duration of the experiment.

\section{Identification of Borers}

Throughout the experiment, live ash trees were monitored for signs of EAB and other borers. Insects emerging from live trees and caught in the enclosures were documented and then destroyed. Harvested trees were removed from their pots and the root ball was cut off. Bark was removed on the bole as well as on the trunk and branches $1 \mathrm{~cm}$ in diameter and larger with a $25.4 \mathrm{~cm}$ draw knife. Borers were identified with the aid of MDA staff and in reference to Johnson and Lyon (1994), Solomon (1995), Herms (2007), and Kalisch and Baxendale (2010). With the exception of $\mathrm{EAB}$, borers were identified to the family according to the following guidelines.

\section{Emerald ash borer}

Individuals were identified by the presence of serpentine, frass-packed galleries, actual beetles or parts of beetles, or D-shaped exit holes. EAB life stage was recorded to determine generation time. Individuals not attaining the fourth larval instar or prepupal stage by winter do not successfully complete development in one year but instead feed through a second summer and emerge the following spring (Duan et al.2010). Life stage in the spring was therefore used as an indicator of generation time. 


\section{Family Sesiidae}

These native Lepidoptera include banded ash clearwing borer (Podosesia aureocincta), which flies in late summer, and ash/lilac clearwing borer (P. syringae), which flies in late spring and early summer (Johnson and Lyon 1994). Characteristic signs of clearwing infestation are large, messy wounds with frass that has been expelled from galleries and remains on or around the tree. Galleries are deep in the sapwood and are not packed with frass (Herms 2007; Kalisch and Baxendale 2010).

\section{Family Cerambycidae}

Roundheaded borers, including the native redheaded ash borer (Neoclytus acuminatus), leave frasspacked but non-serpentine galleries that extend from just under the bark into the sapwood (Herms 2007). Redheaded ash borers typically complete development in one year, with adults emerging in the spring, though there is evidence that a partial second generation can develop within a growing season (Johnson and Lyon 1994). All galleries classified as those of roundheaded borers were considered to be natives, as non-native cerambicids are unknown from ash in locations used in this study.

\section{Family Curculionidae}

Bark beetles leave surface wounds and easily identifiable, ornate, fan-shaped galleries just under the bark. Because identification was performed at the family level and both introduced and native bark beetles feed on ash in eastern North America, the geographic origin of bark beetles in this experiment was unknown.

\section{Statistical Analysis}

All statistical analyses were performed in $\mathrm{R}$ (version 3.0.1, R Development Core Team 2013). Separate contingency table analyses were used to test whether the frequency of trees infested with each type of borer (EAB, Sesiidae, Cerambycidae, Curculionidae) was independent of ash species and watering treatment. Where expected values in the contingency tables were too low and $\chi^{2}$ tests inappropriate, likelihood ratio G-tests were used (g.test function version 2.1, P. Hurd 2001). After evaluating borers separately, the frequency of trees infested by native borers (Sesiidae and Cerambycidae), as well as by any borer (including EAB), was evaluated with contingency table analysis.
Generalized linear models were used to assess whether borer abundance, measured as the number of borers per tree, depended on the single and interactive effects of ash species and watering treatment. For count data, such as the number of borers per tree, a Poisson error structure is often appropriate but requires the variance to be equal to the mean. In this data set, the variance was greater than the mean (e.g., for EAB abundance, variance $=1.87$, mean $=0.89)$, making the Poisson structure inappropriate (Crawley 2007). Negative binomial models fit the data better and were used throughout (glm.nb function in the MASS package, Venables and Ripley 2002). Separate models were developed for EAB, Sesiidae, Cerambycidae, Curculionidae, all natives, and all borers together. For each borer, the significance of model terms was evaluated with likelihood ratio tests.

Because of substantial tree death that had the potential to influence the frequency and abundance of borers in this experiment, analyses were conducted first on the full data set of 96 trees and then on the subset of trees surviving the first summer (75 trees).

\section{RESULTS}

\section{Watering Treatments}

Tree water stress, measured as chlorophyll fluorescence, did not differ significantly before the start of the experiment among trees assigned to different treatments (ANOVA for treatment effect, $F_{2}=$ $1.12, P=0.34)$. Once begun, watering treatments successfully led to differences in tree water stress among treatments $\left(F_{2}=22.16, P<0.001\right.$; Figure 2A). Tree water stress did not differ significantly between the two ash species $\left(F_{1}=1.68, P=0.20\right)$. A slight statistical interaction between treatment and ash species $\left(F_{2}=2.89, P=0.06\right)$ was driven by the low chlorophyll fluorescence of dying trees. Comparing trees in different watering treatments, trees in the low watering treatment exhibited lower chlorophyll fluorescence, that is, greater stress, compared to those in the full and half watering treatments (Tukey's post hoc tests, $P_{a d j}<0.0001$ for both comparisons). Trees in the full and half watering treatments did not differ significantly in chlorophyll fluorescence $\left(P_{a d j}=0.75\right.$; Figure 2A).

In the first two weeks of water restriction, four trees died, and by the end of the first sum- 
mer of the experiment, a total of 21 trees had died. Twenty of those trees had been in the low watering treatment, ten each from green and Manchurian ash; the remaining dead tree was a Manchurian ash in the half watering treatment. Because the chlorophyll fluorescence of the dead and dying trees was very low [ mean $=0.42 \pm 0.06$ (1 SE), $\mathrm{n}=20$ (one tree died before fluorescence could be assessed)], fluorescence was also evaluated for only those trees surviving the first summer of water restriction. Chlorophyll fluorescence of the surviving trees still differed among watering treatments $\left(F_{2}=7.93, P=0.0008\right.$; Figure $\left.2 \mathrm{~B}\right)$ but not species $\left(F_{1}=0.04, P=0.84\right)$ or the interaction between treatment and species $\left(F_{2}=1.56, P\right.$ $=0.22$ ). Post hoc analysis again revealed significant differences between trees in the low watering treatment compared to the full $\left(P_{\text {adj }}=0.0007\right)$ and half watering treatments $\left(P_{a d j}=0.003\right)$.

Because of the similarity in chlorophyll fluorescence among trees in the full and half watering treatments (Figure 2), and because nearly all the trees in those treatments survived, they are considered together as "non-stressed" for the remainder of the analysis. Trees in the low watering treatment are considered "stressed."

\section{Frequency of Borers in Experimental Trees}

All statistics and figures pertain to comparisons of non-stressed (high and half watering treatments together) to stressed trees (low watering treatment).For clarity, data are also presented in Table 1 with respect to original watering treatments for both the full data set of 96 trees and the data set of 75 surviving trees.

EAB more frequently infested green ash compared to Manchurian ash, regardless of water stress (Table 1). This was true across the full data set as well as for surviving trees only. Clearwing borers (Sesiidae) were relatively rare and occurred with nearly equal frequency across ash species and levels of water stress, both for the set of all trees and for the surviving trees only (Table 1). Roundheaded borers (Cerambycidae) were more common in water-stressed trees but were not associated with ash species (Table 1). Only three roundheaded borers were found in surviving trees and were not associated with ash species or water stress. Bark beetles (Curculionidae) were not associated with ash species but occurred in water-stressed trees more frequently than nonstressed trees. This pattern held for both the full data set and among surviving trees only (Table 1). The occurrence of native borers (Sesiidae and

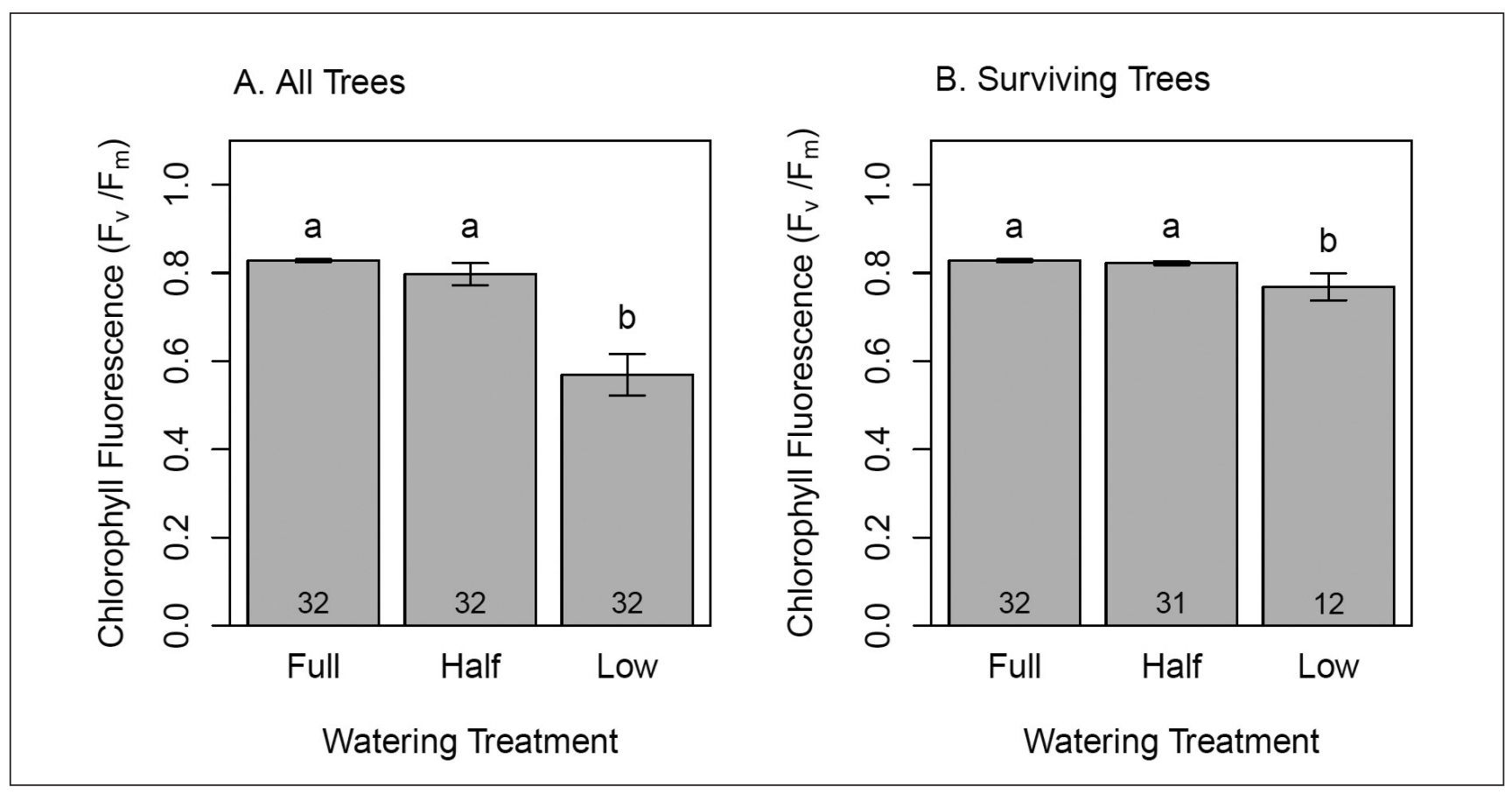

Figure 2. Chlorophyll fluorescence $\left[F_{v}\right.$ (variable fluorescence) / $F_{m}$ (maximal fluorescence)] of ash trees assigned to full, half, and low watering treatments for: $A$ ) all trees in the experiment, and $B$ ) only surviving trees. The number of trees in each treatment is indicated at the bottom of the bars. Letters indicate differences in mean fluorescence among treatments. 
Cerambycidae) was not associated with ash species or water stress (Table 1). Overall, more green ash trees in this experiment were attacked by borers than were Manchurian ash trees, but the frequency of borer infestation did not vary with water stress (Table 1).

No borers were found in the four green ash trees used as cage controls, indicating that the screening and insulation were successful in preventing borer colonization of experimental trees.

\section{Borer Abundance}

The abundance (number of borers per tree) of EAB differed significantly between green and Manchurian ash but was not a function of water stress or the interaction between ash species and water stress (likelihood ratio tests with $\mathrm{df}=1$ throughout; ash species $\times$ water stress interaction: $\chi^{2}=0.69, P=0.41$; water stress: $\chi^{2}=0.01, P=0.93$; ash species: $\chi^{2}=29.71$, $P<0.0001$; Figure 3A). Evaluating EAB abundance in surviving trees, again only the effect of ash species was significant (water stress: $\chi^{2}=1.85, P=0.40$; ash species: $\left.\chi^{2}=25.82, P<0.0001\right)$; the interaction term was not evaluated because EAB were not found in surviving, water-restricted Manchurian ash.

As with the frequency analysis, the abundance of clearwing borers (Sesiidae) did not depend on the simple or interactive effects of ash species and water stress, for the full data set (interaction: $\chi^{2}=0.01, P=$ 0.93; water stress: $\chi^{2}=0.14, P=0.71$; ash species: $\chi^{2}$ $=0.13, P=0.72$; Figure $3 \mathrm{~B}$ ) or among surviving trees only (interaction: $\chi^{2}=0.01, P=0.92$; water stress: $\chi^{2}=1.75, P=0.19$; ash species: $\left.\chi^{2}=0.02, P=0.89\right)$.

Roundheaded borers (Cerambycidae) were more abundant in stressed trees, but abundance was not a function of ash species or the interaction between ash species and water stress (interaction: $\chi^{2}=0.38, P=0.54$; water stress: $\chi^{2}=8.91, P=$ 0.003; ash species: $\chi^{2}=0.54, P=0.46$; Figure $3 \mathrm{C}$ ). Because few roundheaded borers were found in surviving trees (Table 1), the effects of ash species and water stress on roundheaded borer abundance were not evaluated for the set of surviving trees.

As with roundheaded borers, the abundance of bark beetles (Curculionidae) was higher in stressed trees but did not differ among ash species or with the interaction between water stress and ash species (interaction: $\chi^{2}=0.02, P=0.89$; water stress: $\chi^{2}=$ 12.59, $P=0.0004$; ash species: $\chi^{2}=0.46, P=0.50$; Figure 3D). Among surviving trees, only water stress was an important determinant of bark beetle abundance (interaction: $\chi^{2}=0.02, P=0.88$; water stress: $\chi^{2}=6.21, P=0.013$; ash species: $\chi^{2}=0.40, P=0.53$ ).

Table 1. Proportion of trees infested by borers with respect to ash species and water stress (data for surviving trees in parentheses).

\begin{tabular}{|c|c|c|c|c|c|c|c|c|}
\hline & \multicolumn{3}{|c|}{ Green ash } & \multicolumn{3}{|c|}{ Manchurian ash } & \multicolumn{2}{|c|}{$\chi^{2}$ tests } \\
\hline & Full $^{z}$ & Half & Low & Full & Half & Low & Species & Treatment $^{\mathrm{y}}$ \\
\hline $\mathrm{EAB}$ & $\begin{array}{l}0.75 \\
(0.75)\end{array}$ & $\begin{array}{l}0.56 \\
(0.56)\end{array}$ & $\begin{array}{l}0.62 \\
(0.5)\end{array}$ & $\begin{array}{l}0.19 \\
(0.19)\end{array}$ & $\begin{array}{l}0.12 \\
(0.13)\end{array}$ & $\begin{array}{l}0.25 \\
(0)\end{array}$ & $\begin{array}{l}18.9^{*} \\
\left(17.44^{*}\right)\end{array}$ & $\begin{array}{l}0.01 \\
\left(2.03^{x}\right)\end{array}$ \\
\hline Sesiidae & $\begin{array}{l}0.19 \\
(0.19)\end{array}$ & $\begin{array}{l}0.25 \\
(0.25)\end{array}$ & $\begin{array}{l}0.19 \\
(0.33)\end{array}$ & $\begin{array}{l}0.31 \\
(0.31)\end{array}$ & $\begin{array}{l}0.12 \\
(0.13)\end{array}$ & $\begin{array}{l}0.12 \\
(0.17)\end{array}$ & $\begin{array}{l}0 \\
(0)\end{array}$ & $\begin{array}{l}0.21 \\
\left(0.04^{x}\right)\end{array}$ \\
\hline Cerambycidae & $\begin{array}{l}0.12 \\
(0.12)\end{array}$ & $\begin{array}{l}0 \\
(0)\end{array}$ & $\begin{array}{l}0.25 \\
(0)\end{array}$ & $\begin{array}{l}0.06 \\
(0.06)\end{array}$ & $\begin{array}{l}0.06 \\
(0)\end{array}$ & $\begin{array}{l}0.19 \\
(0)\end{array}$ & $\begin{array}{l}0 \\
\left(0.33^{x}\right)\end{array}$ & $\begin{array}{l}4.8^{\star x} \\
\left(1.07^{x}\right)\end{array}$ \\
\hline Curculionidae & $\begin{array}{l}0.06 \\
(0.06)\end{array}$ & $\begin{array}{l}0.06 \\
(0.06)\end{array}$ & $\begin{array}{l}0.19 \\
(0.33)\end{array}$ & $\begin{array}{l}0.06 \\
(0.06)\end{array}$ & $\begin{array}{l}0 \\
(0)\end{array}$ & $\begin{array}{l}0.31 \\
(0.17)\end{array}$ & $\begin{array}{l}0 \\
\left(0.68^{x}\right)\end{array}$ & $\begin{array}{l}8.14^{\star x} \\
\left(4.2^{\star x}\right)\end{array}$ \\
\hline Natives $^{w}$ & $\begin{array}{l}0.31 \\
(0.31)\end{array}$ & $\begin{array}{l}0.25 \\
(0.25)\end{array}$ & $\begin{array}{l}0.38 \\
(0.33)\end{array}$ & $\begin{array}{l}0.31 \\
(0.31)\end{array}$ & $\begin{array}{l}0.19 \\
(0.13)\end{array}$ & $\begin{array}{l}0.25 \\
(0.17)\end{array}$ & $\begin{array}{l}0.21 \\
(0.22)\end{array}$ & $\begin{array}{l}0.058 \\
\left(0.0008^{x}\right)\end{array}$ \\
\hline Any borer & $\begin{array}{l}0.81 \\
(0.81)\end{array}$ & $\begin{array}{l}0.69 \\
(0.69)\end{array}$ & $\begin{array}{l}0.75 \\
(0.67)\end{array}$ & $\begin{array}{l}0.44 \\
(0.44)\end{array}$ & $\begin{array}{l}0.31 \\
(0.27)\end{array}$ & $\begin{array}{l}0.44 \\
(0.17)\end{array}$ & $\begin{array}{l}10.9^{\star} \\
\left(11.21^{\star}\right)\end{array}$ & $\begin{array}{l}0.01 \\
(0.32)\end{array}$ \\
\hline $\begin{array}{l}\text { Number of trees } \\
\text { (Surviving) }\end{array}$ & $\begin{array}{l}16 \\
(16)\end{array}$ & $\begin{array}{l}16 \\
(16)\end{array}$ & $\begin{array}{l}16 \\
(6)\end{array}$ & $\begin{array}{l}16 \\
(16)\end{array}$ & $\begin{array}{l}16 \\
(15)\end{array}$ & $\begin{array}{l}16 \\
(6)\end{array}$ & & \\
\hline
\end{tabular}

${ }^{\mathrm{z}}$ Data are presented for the original watering treatments for illustrative purposes. See Methods for details on watering treatments.

y Test statistics from contingency table analyses compare frequency of borer infestation in stressed (low watering treatment) versus non-stressed trees (full and half watering treatments together).

${ }^{x}$ Due to low expected probabilities, log likelihood ratio $\mathrm{G}$ tests were conducted, with $\mathrm{df}=1$ for each test.

w Includes Cerambycidae and Sesiidae.

Asterisk $\left(^{*}\right)$ denotes significant tests of association $(P<0.05)$. 
Considering native borers together (Sesiidae and Cerambycidae), only water stress significantly influenced borer abundance (interaction: $\chi^{2}=0.49, P=0.48$; water stress: $\chi^{2}=6.91, P=$ 0.009; ash species: $\chi^{2}=0.80, P=0.37$; Figure $3 \mathrm{E}$ ). Because so few roundheaded borers were found in surviving trees, the results for all natives in surviving trees mirror those of clearwing borers only, with neither ash species nor water stress having a significant effect on native borer abundance (interaction: $\chi^{2}=0.03, P=0.85$; water stress: $\chi^{2}$ $=1.07, P=0.30$; ash species: $\chi^{2}=0.10, P=0.75$ ).

For all borers together, borer abundance was higher in green compared to Manchurian ash and in water-stressed trees (interaction: $\chi^{2}=0.96, P=0.33$; water stress: $\chi^{2}=10.62, P=0.001$; ash species: $\chi^{2}=$ $16.14, P<0.0001$; Figure 3F). Considering surviving trees only, the effect of water stress was unimportant, and borer abundance was only affected by ash species (interaction: $\chi^{2}=0.32, P=0.57$; water stress: $\chi^{2}=$ $0.44, P=0.51$; ash species: $\chi^{2}=16.24, P<0.0001$ ).

\section{Phenological Observations for EAB in Maryland}

All EAB individuals discovered while debarking trees in April and May 2010 were in the pre-pupal, pupal, or adult stages, with no evidence of individuals in early stages of larval development. All evidence of EAB detected while debarking trees two years after the initial exposure (February and March 2011) was from dead individuals that apparently had died much earlier. No evidence for a two-year EAB lifecycle was apparent in this study.

\section{DISCUSSION}

Urban canopies can be greatly reduced by EAB where ash is commonly planted (Poland and McCullough 2006; Raupp et al. 2006; Kovacs et al. 2010; Sargent et al. 2013). Along with biological control and chemical treatment of ash, the deployment of resistant woody plant material is a key component of integrated pest management for this insect (Raupp et al. 1992; Herms 2002; Herms and McCullough 2014). In the search for resistant ash stock, Manchurian ash has repeatedly been identified as highly resistant to EAB attack (Figure 3A; Rebek et al. 2008; Herms and McCullough 2014), and where planted, may be the only ash species remaining through the $\mathrm{EAB}$ invasion. If Manchurian ash were to be highly susceptible to North American insects, however, its survival and utility in breeding programs would be compromised. In this study, Manchurian ash was indeed attacked by the suite of indigenous North American borers, but the frequency of borer attack and the abundance of borers in trees was never higher in Manchurian than in green ash trees. These results indicate that Manchurian ash may withstand attack by EAB and the suite of North American borers and be an appropriate source of resistance material for breeding programs and a replacement for North American ash trees in urban settings.

Through evolutionary time, plants develop various mechanisms for resistance against key insect herbivores. The defense free-space hypothesis proposes that native plants that have not evolved to defend against exotic herbivores can be overexploited (Gandhi and Herms 2010a; Raupp et al. 2010). These results provide support for the defense free-space hypothesis as it pertains to EAB. Across levels of plant water stress, EAB was 6.7 times more abundant in green ash compared to Manchurian ash (Figure 3A). These findings corroborate those of several other authors regarding host preferences of EAB (Liu et al. 2007; Wei et al. 2007; Rebek et al. 2008; Pureswaran and Poland 2009).

North American borers, on the other hand, did not strongly prefer native or exotic ash species, with similar frequencies and abundances in green and Manchurian ash (Figure 3E). North American borers, therefore, may not be advantaged by defense free space in Manchurian ash. Experiments have shown that Manchurian ash has a distinct chemical profile likely involved in plant defense (Eyles et al. 2007; Cipollini et al. 2011; Whitehill et al. 2012). These anti-herbivore mechanisms may be general defenses against borers and prevent North American herbivores from successfully exploiting Manchurian ash. Although there is mounting evidence that exotic herbivores frequently find defense free space in their invaded range (Desurmont et al. 2011; Nielsen et al. 2011), it is clear that not all such herbivore-plant interactions lead to herbivore outbreaks (Schierenbeck et al. 1994; Tallamy 2004; Cappuccino and Carpenter 2005). The inconsistent pattern of herbivory between native and exotic plants and insects in this experiment indicates a need for continued experimental approaches and investigations into mechanisms underlying patterns of herbivory. 

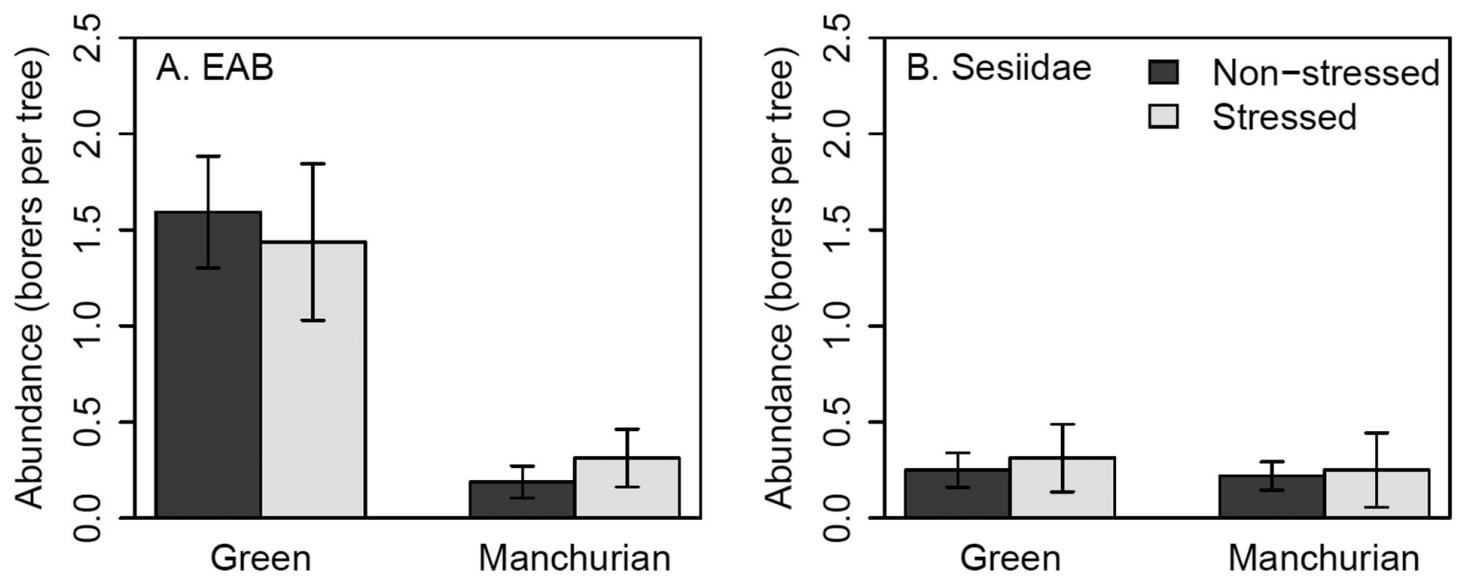

Ash Species
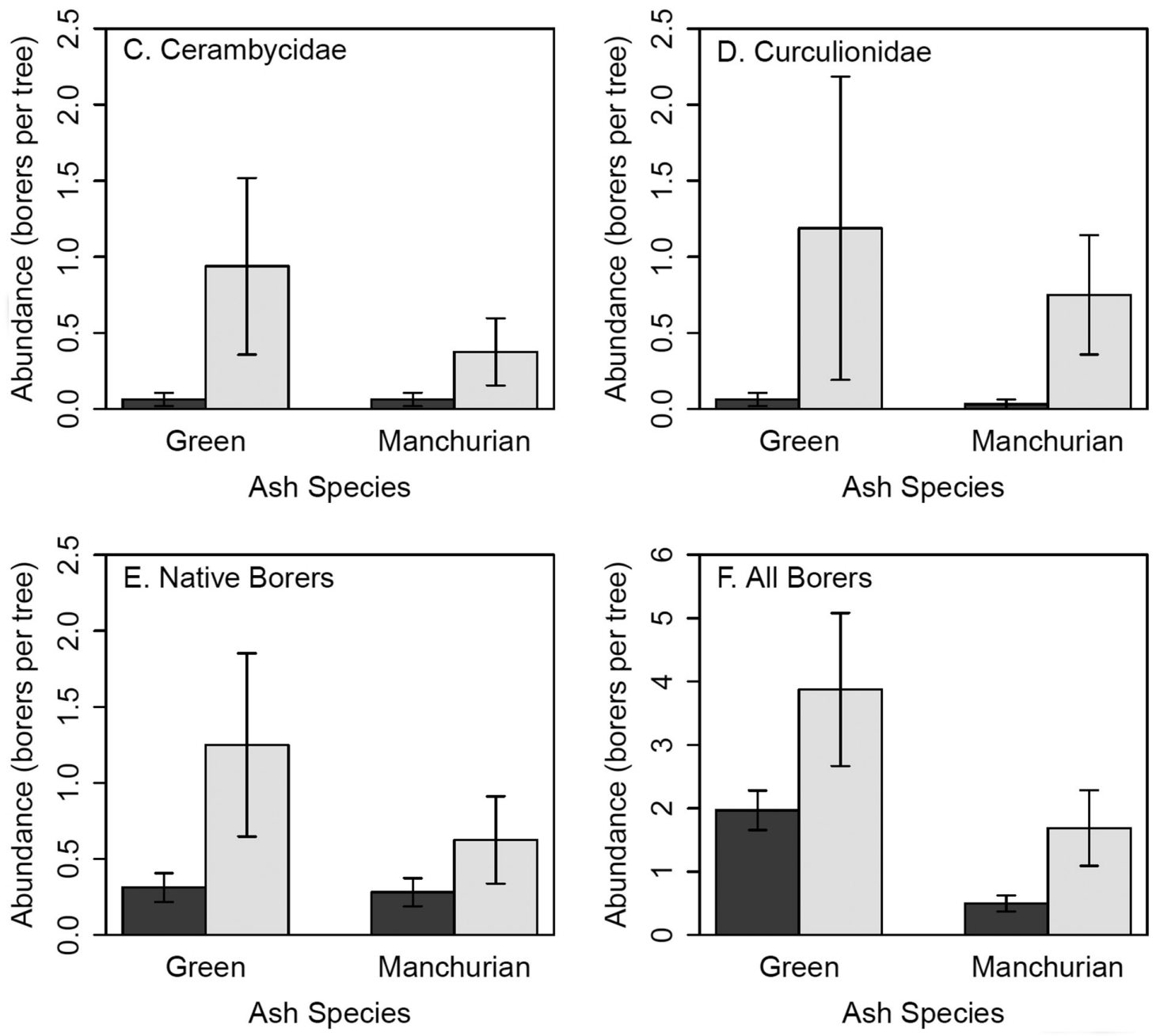

Figure 3. Abundance (mean number per tree $\pm 1 \mathrm{SE}$ ) of borers in experimental green and Manchurian ash trees for: A) emerald ash borer (EAB), B) clearwing borers (Sesiidae), C) roundheaded beetles (Cerambycidae), D) bark beetles (Curculionidae, E) native borers (Sesiidae + Cerambycidae), and F) all borers. Note the difference in scale on the vertical axis in panel F. Dark bars represent non-stressed trees (full and half watering treatments together); light bars represent stressed trees (low watering treatment). Data are from all trees. 
In addition to herbivore resistance, urban plants must also tolerate extreme environmental conditions, such as drought stress (Cregg and Dix 2001; Raupp et al. 2010). Cregg and Dix (2001) found that green ash in the urban environment experienced greater drought stress and suffered greater borer damage compared to those in more natural settings. Indeed, the increase in borer attack in stressed trees is one of the most consistent patterns emerging from studies of herbivory in response to plant stress (Koricheva et al. 1998; Huberty and Denno 2004; Raupp et al. 2010). In the current experiment, the frequency of attack and the abundance of borers in experimental trees increased with tree water stress. This pattern held for both green and Manchurian ash, but there was no evidence for an interactive effect between ash species and water stress. Thus, under conditions of water stress, the relative susceptibility of green and Manchurian ash to borers did not change. This was true in tests for individual borer groups as well as for all borers together (Figure 3F).

These results are from an experiment conducted with potted ash trees, and the results may be limited, in some regards, because of the use of such small trees and the short duration of the experiment. In the hot summers of this experiment (e.g., 60 days above $32.2^{\circ} \mathrm{C}$ ), the ash trees in pots almost certainly experienced more drought stress than trees in natural forests. Additionally, the three original water stress treatments did not lead to a perfect gradient in stress. However, the trees in the low watering treatment were clearly more stressed than those in the full and half water treatments (Figure 2). Insects known to respond to stress, such as bark beetles and redheaded borers, did indeed attack stressed tress more frequently and achieve higher abundances (Figure 3). Clearwing borers, unexpectedly, did not respond to stress. If only the spring-flying Podosesia syringae were present at the exposure site, however, oviposition and much of larval development would have been completed before water stress treatments began and thereby limited its ability to differentially detect and respond to stressed trees. Additionally, population abundances for clearwing moths may have simply been too low to detect treatment effects. Borer attack rates in this study were generally low, with a mean abundance of four borers or fewer per tree (Figure 3F). Further studies should examine the susceptibility of mature Man- churian ash to native borers, where and when borers are more locally abundant, to verify that the results reported here are generalizable under higher pest pressure and for larger Manchurian ash trees.

The use of small, potted trees may have also contributed to the findings that EAB completed development in only one generation at the study sites. EAB was initially thought to have one generation per year, but some reports indicated a two-year lifecycle, especially in outlier populations (Cappaert et al. 2005; Marshall et al. 2009; Duan et al. 2010; Siegert et al. 2010). In a study in Michigan, U.S., Duan et al. (2010) reported that over half of the wild population of $\mathrm{EAB}$ and $100 \%$ of an experimentally established cohort required two growing seasons to complete development. Girdling, however, promotes faster development rates (Tluczek et al. 2011). In the current study, tree water stress did not promote faster development, and tree size cannot be ruled out as a contributing factor. However, the warm Maryland climate may also be important. In forests near the common garden experiment, most natural trees of all sizes showed evidence of a one-year lifecycle, despite evidence for a two-year generation interval at other locations in Maryland (D.E. Jennings, pers. comm.). These results are consistent with findings from China, where EAB is known to have either a univoltine or a semivoltine lifecycle, depending on location (Wei et al. 2004; Wei et al. 2007) and with studies from other Agrilus spp., which require two years to develop in Canada but one in southern New England, U.S. (Tluczek et al. 2011). Together, these findings suggest that EAB may exhibit more rapid population growth and faster spatial spread at the southern part of its invaded range.

Although ash mortality due to EAB infestation varies among cultivars and species of North American ash, these differences have little impact on the ultimate fate of Fraxinus americana, $F$. pennsylvanica, and F. nigra in natural forests and urban settings, all of which typically experience $>99 \%$ mortality (Rebek et al. 2008; Herms and McCullough 2014; Klooster et al. 2014). Manchurian ash, on the other hand, persists well in Asia even where $E A B$ reaches outbreak densities on introduced North American ash (Wei et al. 2004; Baranchikov et al. 2008). Reports from Asia, suggest that $\mathrm{EAB}$ is only a problem when Asian trees such as F. mandshurica and F. chinensis, are highly 
stressed or already declining (Liu et al. 2003; Baranchikov et al. 2008). Additionally, Manchurian ash did not suffer increasing mortality when exposed to EAB in a three-year experiment (Rebek et al. 2008) and has persisted in a long-term experimental plantation near the epicenter of the EAB outbreak (D.A. Herms, pers. comm.). Together, these findings suggest that cultivated and wildtype Manchurian ash should persist through the EAB invasion in North America where water stress is minimized and where edaphic and climatic conditions are favorable (Drenkhan et al. 2014).

Retaining, planting, and breeding Manchurian ash with North American species may be key to sustaining the genus Fraxinus in North America and potentially preserving the multitude of arthropod species that use ash trees during all or part of their lifecycle (Gandhi and Herms 2010b). The researchers suggest that further study of the susceptibility of mature Manchurian ash to North American borers would ensure that planting and breeding schemes are as successful as possible in light of both exotic and North American borers.

Acknowledgments. We are grateful for the help of Mehdi Allaverd, Sarah Bass, Erik Bergmann, Christina Chavez, Samuel Grimard, and Brian Raupp in the field, and Dick Bean, Charles Pickett, Kim Rice, and the staff at the MDA for expertise and assistance. We thank Bill Lamp for technical assistance. Dan Herms and an anonymous reviewer provided valuable comments that improved the manuscript. We are grateful for the donation of ash trees from Bailey Nursery and for field access from the Fairfax County Forestry Division. All work was conducted under an APHIS PPQ 526 permit. This study was conducted in cooperation with the USDA-APHIS-PPQ Center for Plant Health Science and Technology, which also provided funding for the project (Project No. 08-8100-1330-CA). This work was also supported by the USDA National Institute of Food and Agriculture, McIntire Stennis projects 0213895 and 1003486.

\section{LITERATURE CITED}

Baranchikov, Y., E. Mozolevskaya, G. Yurchenko, and M. Kenis. 2008. Occurrence of the emerald ash borer, Agrilus planipennis, in Russia and its potential impact on European forestry. EPPO Bulletin 38:233-238.

Cappaert, D., D.G. McCullough, T.M. Poland, and N.W. Siegert. 2005. Emerald ash borer in North America: A research and regulatory challenge. American Entomologist 51:152-165.

Cappuccino, N., and D. Carpenter. 2005. Invasive exotic plants suffer less herbivory than non-invasive exotic plants. Biology Letters 1:435-438.

Cipollini, D., Q. Wang, J.G.A. Whitehill, J.R. Powell, P. Bonello, and D.A. Herms. 2011. Distinguishing defensive characteristics in the phloem of ash species resistant and susceptible to emerald ash borer. Journal of Chemical Ecology 37:450-459.
Crawley, M.J. 2007. The R Book. Wiley, West Sussex, England. 942 pp.

Cregg, B.M., and M.E. Dix. 2001. Tree moisture stress and insect damage in urban areas in relation to heat island effects. Journal of Arboriculture 27:8-17.

Cumming, A.B., D.B. Twardus, and W.D. Smith. 2006. Maryland and Massachusetts street tree monitoring pilot projects. National Forest Health Monitoring Program NA-FR-01-06. U.S. Department of Agriculture, Northeastern Area State and Private Forestry, Newtown Square, Pennsylvania.

Desurmont, G.A., M.J. Donoghue, W.L. Clement, and A.A. Agrawal. 2011. Evolutionary history predicts plant defense against an invasive pest. Proceedings of the National Academy of Sciences of the United States of America 108:7070-7074.

Drenkhan, R., H. Sander, and M. Hanso. 2014. Introduction of Manchurian ash (Fraxinus mandshurica Rupr.) to Estonia: Is it related to the current epidemic on European ash (F. excelsior L.)? European Journal of Forest Research. DOI: 10.1007/ s10342-014-0811-9.

Duan, J.J., M.D. Ulyshen, L.S. Bauer, J. Gould, and R. Van Driesche. 2010. Measuring the impact of biotic factors on populations of immature emerald ash borers (Coleoptera: Buprestidae). Environmental Entomology 39:1513-1522.

Eyles, A., W. Jones, K. Riedl, D. Cipollini, S. Schwartz, K. Chan, D.A. Herms, and P. Bonello. 2007. Comparative phloem chemistry of Manchurian (Fraxinus mandshurica) and two North American ash species (Fraxinus americana and Fraxinus pennsylvanica). Journal of Chemical Ecology 33:1430-1448.

Gandhi, K.J.K., and D.A. Herms. 2010a. Direct and indirect effects of alien insect herbivores on ecological processes and interactions in forests of eastern North America. Biological Invasions 12:389-405.

Gandhi, K.J.K., and D.A. Herms. 2010b. North American arthropods at risk due to widespread Fraxinus mortality caused by the alien emerald ash borer. Biological Invasions 12:1839-1846.

Haack, R.A. 2006. Exotic bark- and wood-boring Coleoptera in the United States: Recent establishments and interceptions. Canadian Journal of Forest Research-Revue Canadienne De Recherche Forestiere 36:269-288.

Hanks, L.M., T.D. Paine, J.G. Millar, C.D. Campbell, and U.K. Schuch. 1999. Water relations of host trees and resistance to the phloem-boring beetle Phoracantha semipunctata F. (Coleoptera: Cerambycidae). Oecologia 119:400-407.

Herms, D.A. 2002. Strategies for deployment of insect resistant ornamental plants, pp. 217-237. In: Wagner, M.R., K.M. Clancy, F. Lieutier, and T.D. Paine (Eds.). Mechanisms and Deployment of Resistance in Trees to Insects. Kluwer Academic, Dordrecht, The Netherlands.

Herms, D.A. 2007. Distinguishing Emerald Ash Borer from Native Borers. Ohio State University OARDC Extension Publication Fact Sheet. Wooster, Ohio.

Herms, D.A., and D.G. McCullough. 2014. Emerald ash borer invasion of North America: History, biology, ecology, impacts, and management. Annual Review of Entomology 59:13-30.

Huberty, A.F., and R.F. Denno. 2004. Plant water stress and its consequences for herbivorous insects: A new synthesis. Ecology 85:1383-1398.

Johnson, W.T., and H.H. Lyon. 1994. Insects that Feed on Trees and Shrubs, 2nd edition, revised. Cornell University Press, Ithaca, New York, U.S. 
Kalisch, J.A., and F.P. Baxendale. 2010. Insect borers of shade and woody ornamentals. Nebraska-Lincoln Extension Publication EC1580. Lincoln, Nebraska, U.S.

Klooster, W.S., D.A. Herms, K.S. Knight, C.P. Herms, D.G. McCullough, A. Smight, K.J.K. Gandhi, and J. Cardina. 2014. Ash (Fraxinus spp.) mortality, regeneration, and seed bank dynamics in mixed hardwood forests following invasion by emerald ash borer (Agrilus planipennis). Biological Invasions 16:859-873.

Koricheva, J., S. Larsson, and E. Haukioja. 1998. Insect performance on experimentally stressed woody plants: A meta-analysis. Annual Review of Entomology 43:195-216.

Kovacs, K.F., R.G. Haight, D.G. McCullough, R.J. Mercader, N.W. Siegert, and A.M. Liebhold. 2010. Cost of potential emerald ash borer damage in U.S. communities, 2009-2019. Ecological Economics 69:569-578.

Liu, H., L.S. Bauer, R. Gao, T. Zhao, T.R. Petrice, and R.A. Haack. 2003. Exploratory survey for the emerald ash borer, Agrilus planipennis (Coleoptera: Buprestidae), and its natural enemies in China. The Great Lakes Entomologist 36:191-204.

Liu, H.P., L.S. Bauer, D.L. Miller, T.H. Zhao, R.T. Gao, L.W. Song, Q.S. Luan, R.Z. Jin, and C.Q. Gao. 2007. Seasonal abundance of Agrilus planipennis (Coleoptera: Buprestidae) and its natural enemies Oobius agrili (Hymenoptera: Encyrtidae) and Tetrastichus planipennisi (Hymenoptera: Eulophidae) in China. Biological Control 42:61-71.

MacFarlane, D.W., and S.P. Meyer. 2005. Characteristics and distribution of potential ash tree hosts for emerald ash borer. Forest Ecology and Management 213:15-24.

Marshall, J.M., A.J. Storer, I. Fraser, J.A. Beachy, and V.C. Mastro. 2009. Effectiveness of differing trap types for the detection of emerald ash borer (Coleoptera: Buprestidae). Environmental Entomology 38:1226-1234.

Maxwell, K., and G.N. Johnson. 2000. Chlorophyll fluorescence A practical guide. Journal of Experimental Botany 51:659-668.

Nielsen, D.G., V.L. Muilenburg, and D.A. Herms. 2011. Interspecific variation in resistance of Asian, European, and North American birches (Betula spp.) to bronze birch borer (Coleoptera: Buprestidae). Environmental Entomology 40:648-653.

Nowak, D. 2003. New threats to North American forests. pp. 13-16. In: D.A. Hobson, M.L. Tyrell, and A.E. Camp (Eds.). Global Institute for Sustainable Forestry, Yale University, New Haven, Connecticut.

Percival, G.C. 2004. Evaluation of physiological tests as predictors of young tree establishment and growth. Journal of Arboriculture 30:80-91.

Percival, G.C., I.P. Keary, and S. AL-Habsi. 2006. An assessment of the drought tolerance of Fraxinus genotypes for urban landscape plantings. Urban Forestry \& Urban Greening 5:17-27.

Poland, T.M., and D.G. McCullough. 2006. Emerald ash borer: Invasion of the urban forest and the threat to North America's ash resource. Journal of Forestry 104:118-124.

Pureswaran, D.S., and T.M. Poland. 2009. Host selection and feeding preference of Agrilus planipennis (Coleoptera: Buprestidae) on ash (Fraxinus spp.). Environmental Entomology 38:757-765.

R Development Core Team. 2013. R: A language and environment for statistical computing. R Foundation for Statistical Computing, Vienna, Austria.

Raupp, M.J., C.S. Koehler, and J.A. Davidson. 1992. Advances in implementing integrated pest management for woody landscape plants. Annual Review of Entomology 37:561-585.
Raupp, M.J., A.B. Cumming, and E.C. Raupp. 2006. Street tree diversity in eastern North American and its potential for tree loss to exotic borers. Arboriculture \& Urban Forestry 32:297-304.

Raupp, M.J., P.M. Shrewsbury, and D.A. Herms. 2010. Ecology of herbivorous arthropods in urban landscapes. Annual Review of Entomology 55:19-38.

Rebek, E.J., D.A. Herms, and D.R. Smitley. 2008. Interspecific variation in resistance to emerald ash borer (Coleoptera: Buprestidae) among North American and Asian ash (Fraxinus spp.). Environmental Entomology 37:242-246.

Sargent, C., M. Raupp, D. Bean, and A.J. Sawyer. 2010. Dispersal of emerald ash borer within an intensively managed quarantine zone. Arboriculture \& Urban Forestry 36:160-163.

Sargent, C., H.M. Martinson, R.A. Bean, S. Grimard, B. Raupp, S.C. Bass, E.J. Bergmann, D.J. Nowak, and M.J. Raupp. 2013. Approaches for predicting the movement and potential economic and ecological impacts of the emerald ash borer, Agrilus planipennis Fairmaire (Coleoptera: Buprestidae), in Maryland municipalities and a discussion of possible management options. The Maryland Entomologist 6:14-29.

Schierenbeck, K.A., R.N. Mack, and R.R. Sharitz. 1994. Effects of herbivory on growth and biomass allocation in native and introduced species of Lonicera. Ecology 75:1661-1672.

Siegert, N.W., D.G. McCullough, D.W. Williams, I. Fraser, T.M. Poland, and S.J. Pierce. 2010. Dispersal of Agrilus planipennis (Coleoptera: Buprestidae) from discrete epicenters in two outlier sites. Environmental Entomology 39:253-265.

Solomon, J.D. 1995. Guide to Insect Borers in North American Broadleaf Trees and Shrubs. U.S. Dept. of Agriculture, Forest Service. Washington, D.C. 747 pp.

Tallamy, D.W. 2004. Do alien plants reduce insect biomass? Conservation Biology 18:1689-1692.

Tluczek, A.R., D.G. McCullough, and T.M. Poland. 2011. Influence of host stress on emerald ash borer (Coleoptera: Buprestidae) adult density, development, and distribution in Fraxinus pennsylvanica trees. Environmental Entomology 40:357-366.

USDA Forest Service and Michigan State University. 2014. Emerald Ash Borer [the national website on Emerald Ash Borer information]. Accessed 10/07/2014. <www.emeraldashborer.info>

Venables, W.N., and B.D. Ripley. 2002. Modern Applied Statistics with S, 4th edition. Springer, New York City, New York, U.S. 495 pp.

Wei, X., D. Reardon, Y. Wu, and J.H. Sun. 2004. Emerald ash borer, Agrilus planipennis Fairmaire (Coleoptera: Buprestidae), in China: A review and distribution survey. Acta Entomologica Sinica 47:679-685.

Wei, X., Y. Wu, R. Reardon, T.H. Sun, M. Lu, and J.H. Sun. 2007. Biology and damage traits of emerald ash borer (Agrilus planipennis Fairmaire) in China. Insect Science 14:367-373.

Whitehill, J.G.A., A. Popova-Butler, K.B. Green-Church, J.L. Koch, D.A. Herms, and P. Bonello. 2011. Interspecific proteomic comparisons reveal ash phloem genes potentially involved in constitutive resistance to the emerald ash borer. Plos One 6 . DOI: 10.1371/journal.pone.0024863.

Whitehill, J.G.A., S.O. Opiyo, J.L. Koch, D.A. Herms, D.F. Cipollini, and P. Bonello. 2012. Interspecific comparison of constitutive ash phloem phenolic chemistry reveals compounds unique to Manchurian ash, a species resistant to emerald ash borer. Journal of Chemical Ecology 38:499-511. 


\author{
Holly M. Martinson (corresponding author) \\ Department of Entomology \\ University of Maryland \\ College Park, Maryland 20742, U.S.A. \\ hmartins@umd.edu
}

\author{
Chris Sargent \\ Department of Entomology \\ University of Maryland \\ College Park, Maryland 20742, U.S.A. \\ csargen1@umd.edu
}

\author{
Michael J. Raupp \\ Department of Entomology \\ University of Maryland \\ College Park, Maryland 20742, U.S.A. \\ mraupp@umd.edu
}

Zusammenfassung. Der Eschenprachtkäfer ist ein großer Schädling, der aus Asien nach Amerika eingeschleppt wurde. Die asiatischen Eschen sind resistent gegenüber $\mathrm{EAB}$, wahrscheinlich wegen ihrer geteilten evolutionären Entwicklung. Die Resistenz gegenüber einem Schädling bedeutet nicht notwendigerweise auch Resistenz gegenüber anderen. Sollte die asiatische Esche hoch anfällig für nordamerikanische Herbivoren sein, müssten bei dem Einsatz solcher Spezies für Hybridisierung, Züchtungsprogramme und Etablierung in der Landschaft Kompromisse gefunden werden. Allgemeine urbane Probleme, wie Trockenheit können die Käferattaken und die Überlebensrate intensivieren und können die Suche nach resistentem Pflanzenmaterial verkomplizieren. Die Schwerpunkte dieser Studie lagen in der Untersuchung der relativen Anfälligkeit von Grüner Esche(Fraxinus pennsylvanica) und Manchurische Esche (F. mandshurica) gegenüber EAB und einheimlichen Bohrinsekten und ob sich diese Anfälligkeit mit Stress in Trockenheit verändert. In einem allgemeinen Gartenexperiment tauchte der EAB häufiger auf und erreichte bei der Grünen Esche mehr Sättigung als bei der Manchurischen Esche. Die Frequenz und Sättigung von Borkenkäfern (Curculionidae), einheimischen nordamerikanischen Bohrern mit durchsichtigen Flügeldecken (Sesiidae) und langhornigen Käfern (Cerambycidae) war bei beiden Eschen gleich. Obgleich die Anzahl der Bohrinsekten wie erwartet bei den gestressten Bäumen zunahmen, wurde die relative Anfälligkeit von Grüner und Manchurischer Esche nicht verändert. Die Ergebnisse zeigen, das die Manchurische Esche gegenüber vielen Klassen von Bohrinsekten unabhängig von deren geographischen Ursprung resistent ist. Dennoch sollten diese Konklusionen mit Vorsicht betrachtet werden, bis die Ergebnisse in größeren Bäumen verifiziert wurden.

Résumé. L'agrile du frêne (AF), Agrilus planipennis (Coleoptera: Buprestidae), est un bupreste dévastateur introduit en Amérique du Nord en provenance de l'Asie. Le frêne asiatique démontre une résistance à l'agrile du frêne, probablement en raison d'un cheminement évolutif commun. La résistance à un ravageur spécifique ne confère cependant pas nécessairement une résistance aux autres ravageurs. Si le frêne asiatique est très vulnérable aux insectes indigènes nord-américains se nourrissant de matériel foliaire ou ligneux, l'utilité d'une telle espèce pour l'hybridation, les programmes de croisement génétique et leur utilisation aux fins paysagères pourrait être compromise. Des problèmes urbains courants, tels que le stress dû à la sécheresse, peuvent prédisposer à l'attaque d'insectes perceurs et à leur survie, compliquant encore davantage la quête d’espèces résistantes. Les objectifs de cette étude étaient d'examiner la susceptibilité relative du frêne vert (Fraxinus pennsylvanica) et du frêne de Mandchourie (F. mandshurica) à l'agrile du frêne et aux insectes perceurs indigènes, puis de vérifier si cette susceptibilité était altérée lorsque soumise au stress d'une sécheresse. Lors d'une expérience en terrain planté de jeunes arbres, il fut constaté que l'agrile du frêne était plus fréquemment détectée et affectait en populations plus abondantes les frênes verts que les frênes de Mandchourie. La fréquence et l'abondance de scolytes (Curculionidae), de sésies du frêne (Sesiidae), et de longicornes (Cerambycidae) étaient similaires chez ces deux espèces de frênes. Le cycle de génération de l'agrile du frêne était uniformément d'un an et n'était pas influencé par l'espèce de frêne ou le stress hydrique. Bien que les perceurs aient été plus abondants dans les arbres stressés tel qu'anticipé, la susceptibilité relative du frêne vert et du frêne de Mandchourie aux perceurs n'a pas été modifiée. Les résultats suggèrent que le frêne de Mandchourie peut s'avérer résistant à plusieurs types de perceurs, indépendamment de l'origine géographique des insectes, bien que ces conclusions doivent être observées avec une certaine prudence jusqu'à ce que les résultats puissent être vérifiés sur des arbres plus âgés.

Resumen. El barrenador esmeralda del fresno (BEF), Agrilus planipennis (Coleoptera: Buprestidae), es un escarabajo bupréstido devastador introducido en América del Norte desde el Asia. Los fresnos asiáticos exhiben resistencia al BEF debido probablemente a una historia co-evolutivamente compartida. La resistencia a una plaga, sin embargo, no confiere necesariamente resistencia a otras. Debido a que los fresnos asiáticos son altamente susceptibles a los herbívoros de América del Norte, la utilidad de este tipo de especies para la hibridación, programas de fomento y establecimiento en paisajes manejados podría verse comprometida. Los problemas urbanos comunes, tales como la sequía, pueden aumentar el ataque del barrenador y la supervivencia y pueden complicar aún más la búsqueda de material vegetal resistente. Los objetivos de este estudio fueron examinar la susceptibilidad relativa del fresno verde (Fraxinus pennsylvanica) y fresno de Manchuria (F. mandshurica) a BEF y barrenadores nativos y si la susceptibilidad cambia con el estrés por sequía. En un experimento de jardín común, BEF fue más frecuente y alcanza mayor abundancia en fresno verde que en fresno de Manchuria. La frecuencia y abundancia de escarabajos (Curculionidae), barrenadores nativos de América del Norte (Sesiidae), y los escarabajos de cuernos largos (Cerambycidae) fueron similares en las dos especies de fresnos. El tiempo de generación de BEF fue uniforme en un año y no dependía de especies de fresnos o estrés hídrico. Aunque los barrenadores aumentaron como se esperaba en árboles estresados la susceptibilidad relativa de fresnos verdes y de Manchuria al barrenador no cambió. Los hallazgos sugieren que el fresno de Manchuria puede ser resistente a varias clases de barrenadores, independientemente del origen geográfico de insectos, aunque estas conclusiones deberán ser vistas con precaución hasta que los resultados sean verificados en grandes árboles. 